\title{
The Wood Shelving Dilemma
}

\section{Ann Massmann}

Wood shelving puts library materials at risk of damage because wood has an acidic nature and contains other chemical components. Although the best solution is not to use wood at all, many libraries find themselves in a dilemma where wood shelving is already in use or the alternative of steel shelving is not aesthetically acceptable. Finding appropriate solutions for minimizing harm is possible and needed, though a complex series of factors are involved. In addition to sealants or paint, a number of simple yet preservationally sound liners are now available for use on shelves. In this article I present some of the latest preservation information on the subject, in conjunction with one library's solution for mitigating damage from extensive wood shelving.

W ood. So beautiful, so traditional, so damaging to library materials. Yet libraries continue to use wood shelving and ironically sometimes choose to house their most valuable collections on this less-than-ideal shelving material. This is not surprising, as word of the hazards of wood is often still not widespread enough in the library community to counterbalance the aesthetics of the material.

\section{Authors in Preservation Literature Warn of Dangers}

Authors of preservation literature in the library, archives, and museum fields have consistently warned against the use of wood shelving as a long-term option for several decades (Miles 1986; Northern States 2000a; Ogden 1986, 1999b; Ritzenthaler 1983, 1993; SOLINET 2000; Tétreault 1994). But in the library profession in general, the hazards of using wood for shelving are mentioned only very briefly in a few of the books on library planning (Brown, 1995; Leighton 1986, 1999), and in others not at all (Brown 1989; Freifeld 1991; Sannwald 1997; Thompson 1989). The authors that have mentioned the concerns often continue to leave wood shelving as an acceptable, even common option for libraries. Of course, one of the most widespread sources of information for shelving choices continues to be library supplier catalogs, all of which offer extensive selections of wood and wood composite shelving, with no mention of the dangers inherent in this material. As library preservation officer positions and preservation workshops begin to be more widespread, however, an awareness of shelving issues is growing. Regional preservation services such as that of OCLC's AMIGOS in the Southwest and SOLINET in the Southeast, as well as the Northeast Document Conservation Center (NEDCC), the Conservation Center for Art and Historic Artifacts (CCAHA) in Philadelphia, and the Upper Midwest Conservation

Probably the most extensive and up-to-date source on wood and steel shelving issues is Ogden (1999b). This leaflet is from the enormously helpful Preservation of Library \& Archival Materials: A Manual, recently revised and now available online (Ogden 1999a). The Conservation Online Library (CoOL) (2000) offers further information on this and many other topics relating to the 
care of library collections, and includes links to resources by NEDCC, SOLINET, the Abbey Newsletter, and the Western Assocjation for Art Conservation (WAAC), as well as a search engine that allows users to search by topic.

\section{The Problems with Wood Shelving}

Wood shelving is problematic because the woods and adhesives used in its construction emit harmful acids and chemicals. Oak is one of the worst offenders, containing large amounts of acetic acid (Miles 1986; Craddock 1992). Wood composites (plywood, masonite, etc.) usually contain formaldehydes, aldehydes, or potentially damaging acids (Ogden 1999b), though authors in the museum conservation field have reported on several wood composites that might be less damaging if used correctly (Mibach 1994; Northern States 2000b). Unsealed bare wood can be particularly harmful, but so can the coatings used to seal wood as they can also emit harmful chemicals. These acids and chemicals "off-gas" into the surroundings, where they are absorbed by books and papers, speeding the deterioration processes. Other library materials especially audio tapes, video tapes, and photographs_can be damaged when off-gassed chemicals interact with those materials' own chemical composition. Certain metals, as found in plaques and mementos, are also highly reactive to the corrosive effects of these acids.

Closed wooden cabinets and drawer units (such as map cases or microfilm cabinets) are especially dangerous as they enclose and concentrate the emitted gases from the wood. Thus the use of wood for exhibition cases in museums, libraries, and archives has long been a concern. Various preservation information has been produced over the years regarding proper materials for exhibit cases (Craddock 1992). Most recently this includes a new NISO standard, Z39.79-2000 (NISO Forthcoming).

In addition to dangers from off-gassing, there is the possibility of pitch, resin, peroxides, and acids leaching out from the wood and coming into direct contact with the materials stored there (Ritzenthaler 1993). Numerous insects are attracted to wood and might settle in cracks and crevices of cabinets and shelves and move on to the library materials (Kesse 1999). Further, depending on the finish, wood can be highly abrasive to books as they slide across its surface. For these reasons, it is strongly recommended not to use wood shelving or other wood storage equipment to store library materials with long-term value.

\section{Steel Shelving}

Steel shelving is recommended instead of wood. Steel shelving should be finished with a powder-coating - similar to that used for today's high-end patio furniture (Georgia 1997; Ogden 1999b; Ritzenthaler 1993). A baked enamel coating had previously been recommended, but it is now known that an improperly baked-on finish can allow formaldehyde and other volatile substances to leach through (Ogden 1999b). Baked enamel is no longer recommended unless the finish is tested to confirm that it has been correctly applied. Ogden (1999b) offers instructions on how to test steel shelving with the solvent methyl ethyl ketone and a cotton swab. If a wood-look is deemed necessary, then a combination of steel shelving with wood end units or exterior partitions can be purchased or constructed. Shelves in wood cases or cabinets can be removed, for instance, and replaced with steel shelving units inside to provide a partial solution.

National standards for steel library shelving point toward other disadvantages of wood. Among its requirements, ANSI/NISO Z39.73 1994 specifies that steel library shelving be able to bear prescribed loads without sagging or swaying, endure nomal use and cleaning for at least thirty years without signs of wear, and not pose a hazard to books or people (Brown 1995). The correct forms of steel shelving can easily meet these requirements, while few if any wood shelving units can.

Given the many reasons for not using wood shelving, a dilemma in some libraries is how to deal with built-in or other wood shelving that is already installed and not likely to be replaced for reasons of expense or aesthetics. In other libraries, aesthetic concems often continue to override preservation concerns when purchasing new shelving or storage furniture. Given these situations, librarians can make choices to protect their materials stored on wood better.

\section{A Wood Shelving Case Study}

The University of New Mexico's Zimmerman Library presents a good case study of the issues and dilemmas involved in protecting collections against wood shelving. Three of the library's collection locations were in the historic and architecturally significant West Wing, which featured large quantities of built-in, unsealed wood shelving units that had been installed during a renovation in the early 1970s. These three locations were: the Anderson Reading Room, with 245 shelves housing the special collection reference books; the Willard Special Events Room, with 48 shelves housing a locked limited edition collection; and the West Wing, with 48 shelves housing a circulating book collection. As a newer librarian and archivist at Zimmerman Library, and one of several persons concerned about the unprotected wood, I set out to find a solution to care for our books better.

When wood shelving is used for storing library materials, the main concern is to get a barrier between the wood and the materials in contact with it. Ideally, the wood should 
be sealed on all sides, surrounding the materials with a sealant or coating that is not in itself harmful to library materials. Though two-component epoxies, latex, and other paints have been suggested as less harmful than oil-based paints or certain varnishes (Miles 1986; Ogden 1986 and 1999b; Ritzenthaler 1993), moisture-borne polyurethane sealants were most highly recommended in the past by the preservation community (Mibach 1994; Miles 1986; Ogden 1986 and 1999b).

It was in this regard that I began, with the intention of finding the "correct" polyurethane for our wood shelving. Unfortunately, I found that the specific use and formulation considerations of polyurethane for library-shelving purposes did not provide a straightforward solution. In the end, I found that sealants proved to be enormously problematic and unworkable for our situation.

The use of sealants is essentially accompanied by three problems. First, many formulations of polyurethane sealant, including moisture-bome polyurethanes, are now known to contain formaldehyde. Yet because the production specifications for polyurethanes are inconsistent, even the same brand's formulation can change rapidly according to manufacturer desires, and there are no lists of acceptable polyurethanes to help simplify the selection process. For this reason, any polyurethane should be tested before use to ensure that its formulation will not damage the library materials it is intended to protect. Ogden (1999b) provides instructions for testing sealants as well as the wood itself. Testing is time consuming but if not conducted precisely as specified, the results may prove unreliable. In addition, some of the highest quality polyurethanes cost more than $\$ 60$ per gallon, making multiple testings a costly proposition where funding is limited.

The recommended alternative is close consultation with a conservator who can conduct or who has recently conducted such tests and can help make accurate recommendations of safe polyurethanes. When I undertook this project, conservator Pamela Hatchfield of the Museum of Fine Arts in Boston recommended the Camger clear finish 1-146-40 waterborne polyurethane glaze, and the Sterling, Clark, and Lurton "Aqua Coat" epoxy. Though our physical plant's supplier offered lower-cost replacement brand products as equivalents to the recommended products, the intended replacement brand name sealants did not in fact have equivalent compositions when previously tested by Hatchfield. This illustrates why it is essential not to accept at face value any sealants offered as equivalent solutions without proper testing (Hatchfield 1997).

Second, the logistics of applying the sealant is problematic because it requires moving books, patrons, and staff if the area is currently in use. In addition to the displacement from the area while the shelves are being sealed, some sealants can require two to three coats, and all sealants require a period for the finish to cure after application. Three to four weeks is generally recommended by preservation specialists as a curing and off-gassing period (Ogden 1999b).

Third, in many cases the coatings have only a temporary effect in sealing the wood, lasting an unspecified number of years, before needing to be reapplied. We considered this a fatal flaw.

\section{The Second Solution}

Although in a perfect world a polyurethane would have been the best solution, it was because of imperfect reality that I looked for other remedies to our situation. In addition to the use of sealants, I found that there are a number of barrier or liner materials that can be used to separate the wood from library materials. For older wood that has had time to off-gas the most harmful of its acids and chemicals, a liner can be an acceptable solution in place of using sealants. For newer wood, a liner can (and in many cases should) be used in addition to a sealant coating.

An appropriate liner should provide a physical barrier between the wood and the library material while not further damaging the materials themselves. One of the simpler materials often recommended is polyester film (Mylar D or Melinex 516), 5 mil or heavier, held down with double-sided tape (3M \#415). Mylar and tape are available from most archival and preservation suppliers. Liners can also be made from $100 \%$ ragboard or acid-free/lignin-free/alkalinebuffered board from archival suppliers. Ragboard, however, has not been shown to provide a sufficient barrier by itself and should be used in tandem with another material (Ogden 1999b).

Other possibilities for liners include glass, Plexiglass, or MicroChamber folder paper (containing activated charcoal and alkaline buffers). These last two materials both absorb gases, and so will need to be changed over a period of time. Mibach (1994) also has reported on an adhesive coated polyester sheet, Flexmark P M 150C, to seal wood composites such as Gatorboard and Masonite.

An important consideration in selecting a liner is how well the material forms a vapor barrier, blocking corrosive gasses from migrating. A multilayered, laminated foil product, MarvelSeal 360 (a nylon-aluminum-polyethylene laminate) or MarvelSeal 470 (a polypropylene-aluminum-polyethylene laminate) is recommended most often today for the purpose of providing a strong vapor barrier (Bachmann 1992; Burke 1992; Ogden 1999b). It can be used to line wood shelves or display cabinets, and has recently become available in rolls from University Products and Gaylord, as well as from its manufacturer, the Ludlow Corporation. Another acceptable high barrier film is Alcar, a PCTFE (polychlorutrifluorethylene) (Ogden 1999b). These and numerous other materials are 
listed in the appendix of the NISO standard on exhibiting library and archival materials (NISO Forthcoming).

From among these choices of liners, we eventually selected two types for our library, keeping in mind that aesthetics were vitally important, that we had a large number of shelves to cover, and that the wood shelving, though unsealed, had already had many years to off-gas its worst acids. For the Anderson Reading Room and the Willard Special Events Room, we chose to lay glass on top of each wood shelf. We chose this as an aesthetic, durable, and chemically stable barrier that would form an acceptable vapor barrier for this older wood. Other advantages to the glass were that it could be cleaned as needed, and the ease with which books could move across it. (The unsealed, rough wood shelving had been very abrasive to the bottom of books in the high-use reading room collection.) Because the glass only covers the surface on top of which the books are resting, we also use book ends to prevent the books from leaning against either end of the shelving, and we endeavor to keep the books several inches from the back of the shelving.

The glass we selected was clear-float, 3/16-inch thick, with simple seamed edges, unpolished and unoiled. An oil similar to motor oil is often used along the edges of the glass to give it a deeper color, but unoiled glass is preferable. For 293 shelves, varying from 14 to 43 inches long, we paid just under $\$ 2,000$ in 1998 . We considered this worth the price for finding what promises to be a long-lasting and durable barrier to the wood. And for the large number of shelves to be lined, the labor-saving use of the glass company-which cut, seamed, and installed each sheet of glass-was well worth the price.

We selected a different barrier, however, for the shelving in our open, circulating West Wing Collection. The head of the Circulation Department was concerned that a glass shelf might slip off and injure a patron in this open, unsupervised area. Although soft plastic circles were available from the glass dealer that could be placed under the corners of the glass to prevent this, it was enough of a concern that we chose a different barrier for these shelves. Here we used mat board wrapped in Mylar D polyester. We selected mat board instead of Mylar alone for aesthetic reasons. Because many of the shelves were not completely full of books and the area needs to look its best, we chose a brown mat board that matched the color of the shelves. The board was cut to size with the grain running perpendicular to the long edge of the board to prevent the ends of less-than-full shelves from curling up. These mat boards were then wrapped in Mylar D, which was creased along both long edges and fastened underneath with double-sided tape. More of this tape was used directly on each shelf to prevent the liner from slipping off the shelving.

While some compromise was made for aesthetic reasons (i.e., not using MarvelSeal or similar material), the advantages of this barrier include a smooth, nonabrasive, cleanable surface for books to move across. As the Mylar becomes scratched, new Mylar can replace it. Also, the cutting and encapsulating process can be done in-house by students and staff as time permits, saving labor costs. For this project's 48 shelves, we used: mat board ordered through a local art supply store, which cost approximately $\$ 90$; one roll of archival polyester, 4 mil thick, $40^{\prime \prime} \times 100^{\prime \prime}$, from an archival supply company, which cost \$133; and several rolls of dorble-face tape at $\$ 5$ each. The total cost was $\$ 233$.

An especially important advantage to both the Mylar and the glass liners was that their installation caused minimal disruption to patrons, staff, and collections compared to a project to seal those same shelves.

\section{Conclusions}

Wood shelving puts library materials at risk of damage because wood has an acidic nature and contains other chemical components. Finding appropriate solutions for minimizing harm is possible and needed. Though a complex and sometimes baffling series of factors are involved, solutions are in fact available when wood shelving is already present in an area or the alternative of steel shelving is not acceptable. In addition to sealants or paint, a number of simple, yet preservationally sound liners are now available. The liner options have various advantages and disadvantages depending on the nature and use of the shelving and the available budget and staffing of the library. By presenting the latest preservation information and my own library's solutions relating to the nature and consequences of using wood shelving, I hope that others with similar wood shelving dilemmas will be able to find practical solutions to protect library materials from the dangers posed by wood.

\section{Works Cited}

Abbey Newsletter. 1999. Cooperative Conservation Centers in the U.S. Abbey newsletter 23, no. 4. Accessed March 14, 2000, http://palimpsest.stanford.edu/byorg/abbey/an/an23/an234/an23-406.html

Bachmann, Konstanze, and Rebecca Anne Rushfield. 1992. Principles of storagc. In Conservation concerns: A guide for collectors and curators, edited by Konstanze Bachmann Washington D.C.: Smithsonian Institution Press.

Brown, Carol R. 1989. Selecting library furniture: A guide for librarians, designers, and architects. Phoenix: Oryx Press. 1995. Planning library interiors: The selection of furnishings for the 21st century. Phoenix: Oryx Press.

Burke, John. 1992. Vapor barrier films. WAAC (Western Association for Art Conservation) Newsletter 14, no. 2: 13-17.

Conservation Online Library (CoOL). 2000. Resources for profes sionals. Accessed March 14, 2000, http://palimpsest.stanford. edu. 
Craddock, Ann Brooke. 1992. Construction materials for storage and exhibition. In Conservation concerns: A guide for collectors and curators, edited by Konstanze Bachmann. Washington D.C.: Smithsonian Institution Press.

Freifeld, Roberta, and Caryl Masyr. 1991. Space planning in the special library. Washington, D.C.: Special Libraries Association.

Georgia Department of Archives and History, Office of Secretary of State. 1997. Selecting an off-site records facility. March 31. Accessed March 14, 2000, http:/palimpsest.stanford.edu/ byorg/georgia/offsite.htmil.

Hatchfield, Pamela. 1997. Telephone conversation with the author. March 16.

Kesse, Erich. 1999. Know the signs of insect infestation. University of Florida Libraries, Preservation Bulletin 7.1. January. Accessed Mar. 14, 2000, http://palimpsest.stanford.edu/ byauth/kesse/kessesgn.html.

Leighton, Philip D., and David C. Weber. 1986. Planning academic and research library buildings. $2 \mathrm{~d}$ ed. Chicago: ALA. . 1999. Planning academic and research library buildings. 3d ed. Chicago: ALA.

Library Journal. 1986. Treating wood shelving to protect books. Library Journal 111, no. 15: 28.

Mibach, Lisa. 1994. Technical exchange. WAAC (Western Association for Art Conservation) Newsletter 16, no. 2: 19-20.

Miles, Catherine E. 1986. Wood coatings for display and storage cases. Studies in conservation 31: 114-24.

Morse, Elizabeth. 1994. Supplies \& services. Abbey Newsletter 18, no. 8 .

National Information Standards Organization. Forthcoming. Proposed American national standard: Environmental conditions for exhibiting library and archival materials, NISO Z39.79-2000. Washington D.C.: NISO.

Northem States Conservation Center. 2000a. Storage guidelines. January 22. Accessed March 14, 2000, www.collectioncare.org/ cci/ccis.html. 2000b. Shelving. January 27. Accessed March 14, 2000, www.collectioncare.org/cci/ccissh.html.

Ogden, Sherelyn. 1986. Treatment of wooden shelving for books. New Library Scene 5, no. 4: 18.

. 1999a. Preservation of library \& archival materials: A manual. $3 \mathrm{~d}$ ed. Andover, Mass.: Northeast Document Conservation Center. Accessed March 14, 2000, www.nedcc.org/ plam3/manhome.htm.

- 1999b. Storage furniture: A brief review of current options. In Preservation of library \& archival materials: A manual. 3d ed. Andover, Mass.: Nurtheast Docuntent Conservalion Center. Accessed March 14, 2000, www.nedcc.org/plam3/ tleaf42.htm.

Patkus, Beth. 1997. Telephone conversation with the author. April 18.

Regional Alliance for Preservation. 2000. February 25. Accessed March 14, 2000, http://rap.solinet.net/.

Ritzenthaler, Mary Lynn. 1983. Archives and manuscripts Conservation. Chicago: Society of American Archivists. 1993. Preserving archives and manuscripts. Chicago: Society of American Archivists.

Sannwald, William W. 1997. Checklist of library building design considerations. $3 \mathrm{~d}$ ed. Chicago: ALA.

Smith, Steve. 1997. Telephone conversation with the author March 3.

SOLINET. 2000. Handling books in general collections. Preservation services leaflet. January 7 . Accessed March 14, 2000, http://palimpsest.stanford.edu/solinet/hndlbook.htm.

Tétreault, Jean. 1994. Display materials: the good, the bad, and the ugly. In Exhibitions and conservation: Pre-prints of the conference held at the royal college of physicians, Edinburg, ed. J. Sage, 79-84. Edinburg, Scotland: Scottish Society for Conservation \& Restoration. Accessed March 14, 2000, http://hjem.get2net.dk/ryhl/good-bad-ugly.htm.

Thompson, Godfrey. 1989. Planning and design of library buildings. $3 \mathrm{~d}$ ed. London: Butterworth Architecture. 